\title{
Abundance and Diversity of Butterfly in Ntakata Forest, Western Tanzania
}

\author{
Ally K Nkwabi ${ }^{1,3 *}$, Sood A Ndimuligo ${ }^{2}$, Steven D Liseki ${ }^{3}$, Fredrick P Mhalafu ${ }^{4}$, Baraka M Naftal ${ }^{1,3}$, David A Collins ${ }^{2,5}$, \\ Simula P Maijo, ${ }^{1,3}$, Iddi Lipende ${ }^{1,3}$, John K Bukombe ${ }^{3}$, Hamza K Kija ${ }^{3}$ and Pius Y Kavana ${ }^{1,3}$ \\ 1 Western Wildlife Research Centre, Tanzania
}

2The Jane Goodall Institute, Tanzania

3Tanzania Wildlife Research Institute (TAWIRI), Tanzania

4Tanzania National Parks, Tanzania

5Gombe Stream Research Centre, the Jane Goodall Institute, Tanzania

Submission: May 25, 2021; Published: June 14, 2021

*Corresponding author: Ally K Nkwabi, Western Wildlife Research Centre, Tanzania Wildlife Research Institute (TAWIRI), P.0.Box 1053, Kigoma, Tanzania

\section{Abstract}

Species loss on the earth occurs at an increasingly high rate. The damage mainly caused by human pressure to the environment from both outside and within protected areas in Africa, calling for immediate actions to establish baseline data on species richness, abundances, and diversity. Then, we can compare future surveys and conservation efforts. In this study butterflies were selected because they are meaningful, indicate essential environmental change, and are suitable for detecting conservation concern and prioritizing conservation priority efforts. A total of 45 sample points at every $200 \mathrm{~m}$ creating fifteen points in each transect in three transects of $3 \mathrm{~km}$ long, was established. Each transect covered all the important habitat types in the study area, including open and closed woodland, grassland and forest. Butterfly data was collected from the $25^{\text {th }}-29^{\text {th }}$ of April 2018 and documented butterfly species richness and diversity in the Ntakata Forest of western Tanzania. We used hand-held butterfly net and visual observation in data collection. Non-parametric Kruskal-Wallis test and Jaccard similarity coefficient was used to examine differences in multiple independent samples among habitat types. We collected 454 butterfly individuals belonging to 5 families, 57 genera and 96 species. Forest habitat had highest number of species (with 19) while grassland accommodated the least number with six species. Therefore, forest habitats were ideal for butterflies' survival. However, increasing human activities like settlement, farming and grazing will ruin and affect butterfly species. Consequently, we suggest adjacent human communities be involved in the conservation of biodiversity.

Keywords: Butterfly; Abundance; Diversity; Habitat types; Ntakata forest; Western tanzania

\section{Introduction}

Species loss occurs at an increasingly high rate from both outsides and within protected areas in Africa, calling for immediate actions to establish baseline data on species richness, abundances, and diversity. Future surveys and conservation efforts can be compared [1]. For a long time now, in western Tanzania, small animal taxa received the least attention in research and conservation, and most surveys focused on large mammals; e.g. on ungulates see Caro et al. [2], on primates [3-6]. However, in recent times is progressively more recognized that smaller species are essential for ecological and conservation monitoring because some are particularly sensitive to pollution and habitat modifications [7-9].

For example, selective logging significantly affects some tropical butterfly species composition [10-12]. Still, it may not affect ungulates or carnivores to the same degree. Butterfly species richness provides good bio-indicators in conservation planning in Africa [13]. However, most habitats in the world today are subject to human disturbances; pollution, fires, overgrazing, invasive species, habitat fragmentation and modification [1416]. The human-induced disturbances have resulted in a species diversity crisis worldwide. Several thousands of species of both plants and animals are affected, and in the process, many species are being lost unnoticed [17].

Therefore, the animal survey of both large and small species is very important for conservation because wildlife management requires information about the different types and distribution of animal species found within an area. All management approaches focus on species distribution and how capable they are to 
respond to changes in their environment, enabling appropriate management strategies backed up by scientific evidence.

The Ntakata Forest harbors' wildlife species, including the endangered eastern chimpanzees (Pan troglodytes schweinfurthii). Others include non-human primates, mammals, avifauna, reptiles, amphibians and insects $[5,18,19]$. Currently, the Forest face threats from human activities, namely tree felling for cultivation, fuel wood, charcoal extraction and livestock grazing [20]. Other threats include mining activities in Tongwe area [21]. Such activities remove certain plant species necessary as food for caterpillars and nectar for adults, which is disastrous for their survival [22]. For example, Hoyle \& James [23] showed that the act of grazing by farm animals threatens many plant species, which in turn affects the butterfly species diversity as it causes temperature variations that can cause butterfly deaths. Furthermore, James et al. [24] indicated that continuous grazing could lead to the extinction of the whole population of certain butterfly species.

Given these threats, it is imperative to acquire baseline information on butterfly species richness, abundance and diversity to compare future studies. Therefore, this study sought to document data on butterfly abundance, composition and species diversity from Ntakata Forest, Results from this study are important for future monitoring and conservation actions in western Tanzania. Ntakata Forest is a pristine forest in west Tanzania, remotely located from human settlements and consists of more forest than woodlands. It has abundant chimpanzees $[5,25]$ and Ashy red colobus monkeys (Piliocolobus tephrosceles) [26], both of which are endangered species and are still well focused.

\section{Methods and Materials}

\section{Study site}

We conducted this study in the Ntakata Forest located at $\left(05^{\circ} 45^{\prime}-06^{\circ} 15^{\prime} \mathrm{S}, 30^{\circ} 00^{\prime}-30^{\circ} 15^{\prime} \mathrm{E}\right)$, situated approximately $27 \mathrm{~km}$ due east of the mouth of Luegele River (Figure 1). The forest is mainly in the valley bottoms of submontane and montane forest types, and the other habitat types are woodland, wooded grasslands, swamps and grassland in hill areas [25]. In addition, there are rare and threatened species of plants such as Dalbergia melanoxylon. The Ntakata Forest is a series of small forest in miombo woodlands, dominated by Garcinia huillensis, Albizia glaberrima, Chionanthus africana, Julbernardia unijugata and Teclea sp. [25]. The elevation varies from $1094 \mathrm{~m}$ to $1802 \mathrm{~m}$ above sea level (Figure 1). The rainfall pattern in the Ntakata forest is unimodal, spanning from November to April and the dry season in the area extends from May to October [25].

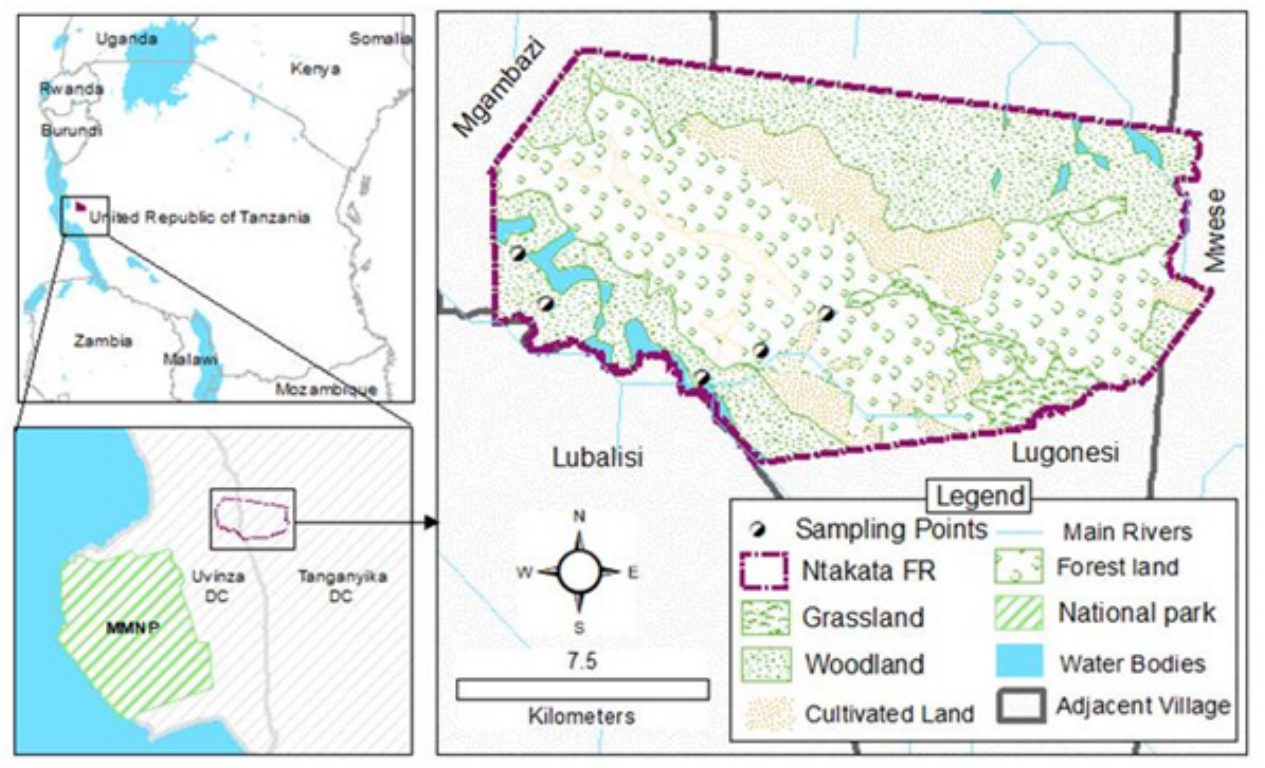

Figure 1: Map of Ntakata Forest showing habitats surveyed and the location of butterfly sampling points.

\section{Butterfly collection design}

We established 45 sampling points in three transects of $3 \mathrm{~km}$ long within Ntakata forest covering all the important habitat types considered in this study (i.e., open and closed woodland, grassland and forest). In each transect, we established a butterfly collection points at every $200 \mathrm{~m}$ creating fifteen points in each transect and collected butterfly from $25^{\text {th }}-29^{\text {th }}$ of April 2018. Each point and transect was sampled using two complementary methods. Firstly, we collected butterflies using a hand-held butterfly net $(35 \mathrm{~cm}$ in diameter) following Nkwabi et al. [27]. We performed random searches in each point in transect by four to five collectors for 5 
hours for each trap day from morning (09:00hrs. to 12:00hrs.) and from $15: 00 \mathrm{hrs}$ to $17.00 \mathrm{hrs}$ in the evening. We conducted timed sweep netting within each habitat type and recorded data on species type and the associated habitat types on standardized data sheets. We kept unidentified individuals in special envelopes and later identified them to species level by the aid of field guide books of [28-30].

Secondly, the transect method was used involving visual observation of flying butterflies along transects [31-33]. We conducted the visual observation method in the same plot before a hand-held butterfly net. We used the technique to record butterfly species that are common and easy to identify to avoid over collection. The method involved counting the number of flying butterflies that crossed a strip of known length (somewhere between $30 \mathrm{~m}$ and $60 \mathrm{~m}$ ) and $20 \mathrm{~m}$ wide for 10 minutes and recorded the time-lapsed by Casio hand-held stopwatch [33].

\section{Statistical analysis}

Prior to analyses, we tested normality using the ShapiroWilk (W) Test. In addition, we used a non-parametric KruskalWallis (K.W.) test to examine differences in multiple independent samples among habitat types.

We calculated species richness estimates following Seaby \& Henderson [34]. This index uses three biodiversity indices including, richness, diversity and abundance, to explain which habitat types had the highest biodiversity for the butterfly community.

We further calculated butterfly species composition similarity between habitat types: open woodland, forest, closed woodland and grassland using Jaccard similarity coefficient $(\mathrm{J})=\mathrm{A} /(\mathrm{A}+\mathrm{B}+$ C) [35], where: $A=$ number of species found in both communities, $\mathrm{B}=$ number of species found in community 1 and $\mathrm{C}=$ number of species only found in community 2 . The equation returns a number between 0 and 1 , where a number close to 1 indicates higher similarity in species composition [35] and multiplied by the coefficient by 100 to reasonably interpret the results.

\section{Results}

We collected 454 butterfly individuals belonging to 5 families, 57 genera and 96 species (Appendix 1). We recorded four habitat types in the study area: forest. We observed 19 species, closed woodland (10), open woodland (13), grassland (6), two species were foraging in four mentioned habitats, and 46 species were foraging in two or three habitat types (Figure 2, Appendix 1). Overall, $80 \%$ were in all habitat types and $20 \%$ were in the forest, open and closed woodland (Figure 2). Nymphalidae had the highest number of species (48), followed by Hesperiidae (16), Pieridae (12), eleven species in Lycaenidae and Papilionidae had only 9 species. Species richness in each family differed significantly across habitat types (Kruskal-Wallis rank-sum test, $\left(\chi^{2}=8.099, \mathrm{df}\right.$ $=5, \mathrm{P}<0.044)$.

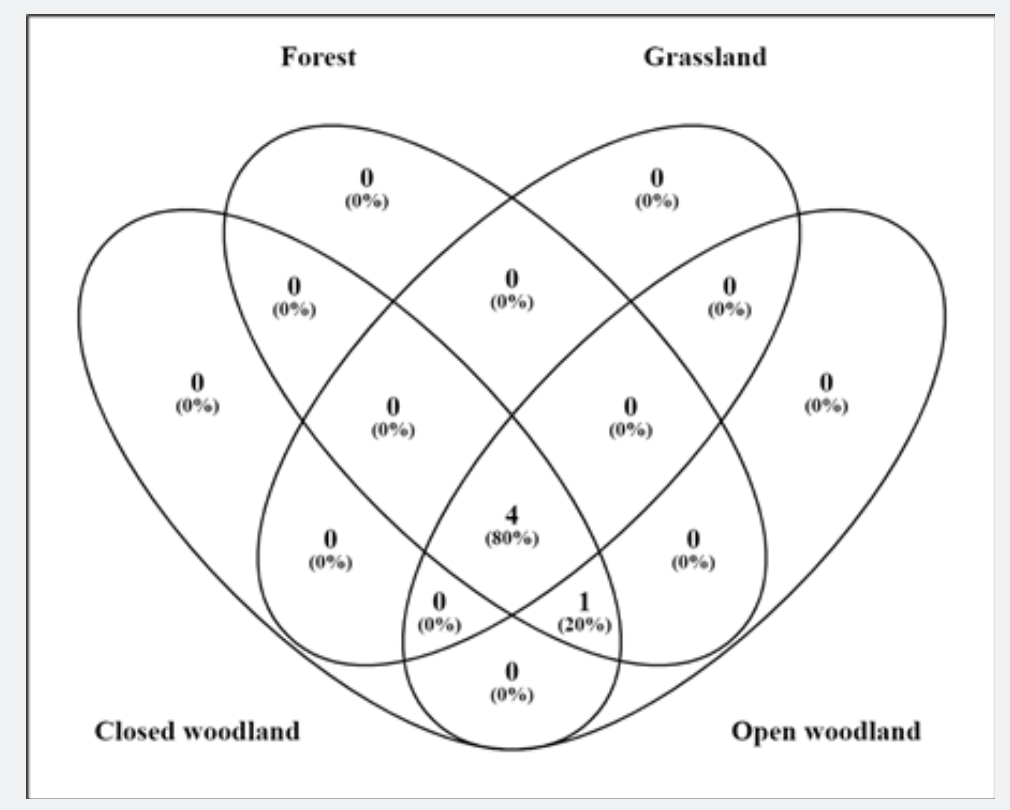

Figure 2: Butterfly species observed foraging in different habitat types. From the Venn diagram 1 represents common element that is Papilionidae occurring in "closed woodland", "forest" and "open woodland": Number 4 in the Venn diagram represents common elements (Nymphalidae, Lycaenidae, Pieridae and Hesperiidae) observed in all habitats. 
The mean abundance of butterflies differed significantly $\left(\chi^{2}=\right.$ 5.018, $\mathrm{df}=5, \mathrm{P}<0.039$ ) among families and among habitat types $\left(\chi^{2}=4.518, \mathrm{df}=4, \mathrm{P}<0.009\right)$. The mean abundance (mean $\left.\pm \mathrm{SE}\right)$ of butterflies was higher in open woodland $1.98 \pm 0.39$, followed by forest $1.30 \pm 0.17$, closed woodland $1.28 \pm 0.36$ and least in grassland $0.17 \pm 0.06$ (Figure $3 \mathrm{~A}$ ). At family level, Nymphalidae had higher mean abundance of $2.66 \pm 0.66$, followed by Lycaenidae $0.91 \pm 0.47$, Pieridae $0.49 \pm 0.22$, Hesperiidae $0.39 \pm 0.0 .103$ and $0.28 \pm 0.12$ for Papilionidae.

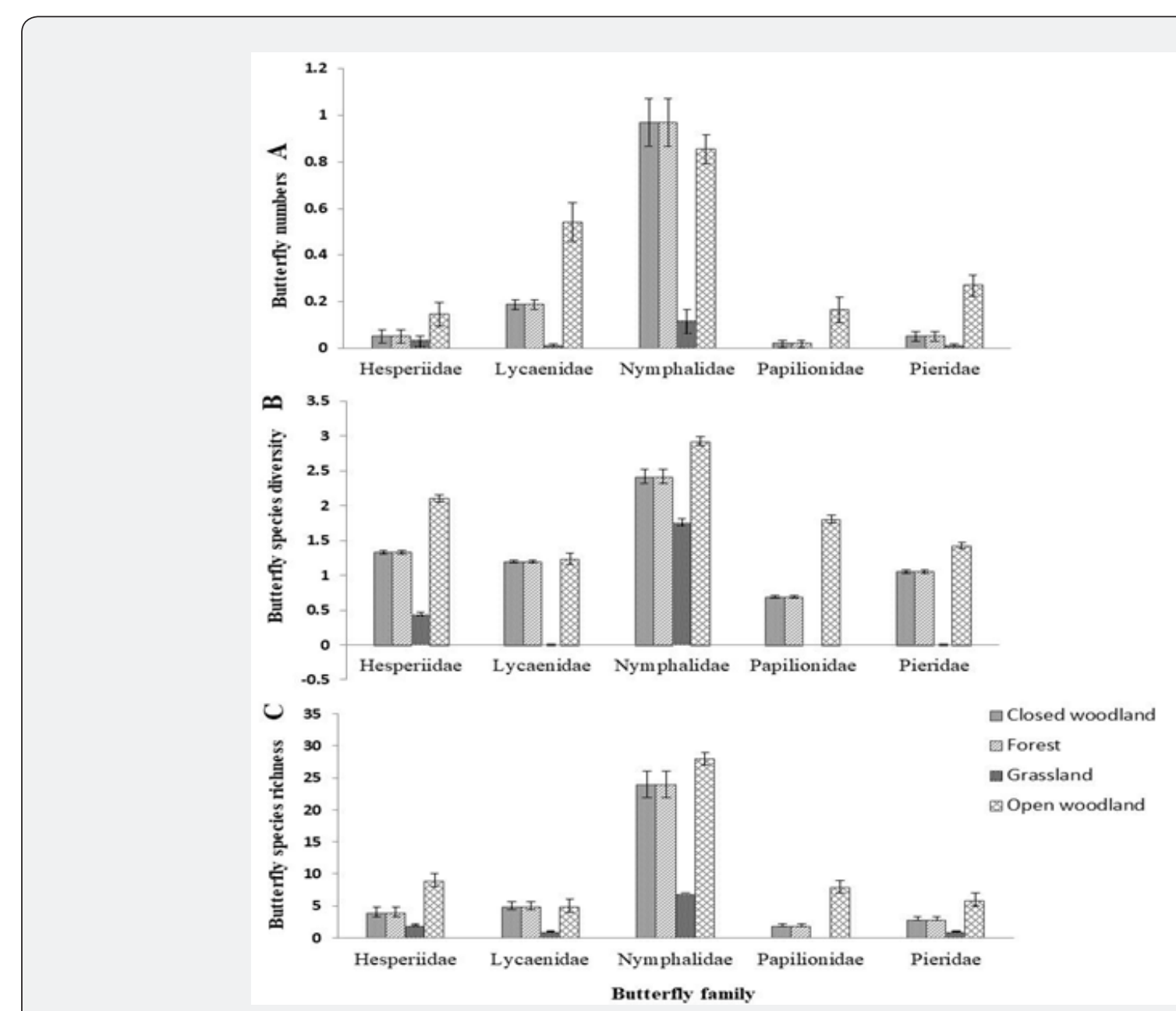

Figure 3: Butterfly (mean \pm SE) species abundance $(A)$, diversity $(B)$ and richness $(C)$ distributed across different families in habitat types of Ntakata Forest.

Species diversity and richness of the five families: Nymphalidae, Hesperiidae, Papilionidae, Pieridae and Lycaenidae were higher in the open and closed woodland and forest habitat than in the grassland (Figure 3B \& 3C). Species diversity was higher in forest $\left(\mathrm{H}^{\prime}=3.87\right)$, followed by open woodland $\left(\mathrm{H}^{\prime}=3.49\right)$, closed woodland $\left(\mathrm{H}^{\prime}=2.93\right)$ and least in grassland $\left(\mathrm{H}^{\prime}=2.25\right)$. Mean species diversity (mean \pm S.E.) of the butterfly was relatively higher; Nymphalidae was more diverse in open woodland, 3.15 \pm 0.06 than other families and habitats. Similarly, Nymphalidae was in closed woodland and forest with mean diversity of 2.42 \pm 0.03 , and the least mean diversity was in grassland whereby Hesperiidae had mean diversity of $0.44 \pm 0.02$ and the difference in mean diversity of butterfly calculated differed significantly $\left(\chi^{2}\right.$
$=8.049, \mathrm{df}=5, \mathrm{P}<0.043$ ). No butterfly species in Papilionidae was in grassland habitat type (Figure 2).

We found significant variability in species composition similarities among habitat types (Table 1). Higher Jaccard similarity index (J) was between open woodland vs forest, open woodland vs closed woodland and closed woodland vs forest (Table 1). Forest vs grassland had a small similarity index (J) (Table 1). Even though the Jaccard similarity index (J) scale varies from 0 to 100 , where values closer to 100 means higher similarities [35], these results show that most comparisons were below 0.5 (50\%) similarities in species composition. Common species were more between open woodland vs forest (33) and closed woodland vs forest (22) (Table 1). 
International Journal of Environmental Sciences \& Natural Resources

Table 1: Species composition similarities between habitat types in Ntakata Forest.

\begin{tabular}{|c|c|c|c|c|}
\hline Habitat Types Compared & Common Species (A) & Species in B & Species in C & Index (J)*100 \\
\hline Open woodland vs Closed woodland & 21 & 32 & 29 & 32 \\
\hline Open woodland vs Forest & 33 & 20 & 13 & 23 \\
\hline Open woodland vs Grassland & 16 & 37 & 40 & 30 \\
\hline Closed woodland vs Forest & 22 & 12 & 17 & 29 \\
\hline Closed woodland vs Grassland & 15 & 19 & 17 & 19 \\
\hline Forest vs Grassland & 15 & 47 & & 23 \\
\hline
\end{tabular}

\section{Discussion}

Forested areas in Tanzania are rich in butterflies [28]. In this study, we recorded 96 species belonging to 5 families. According to Kielland [28], Tanzania has seven families of butterflies; the occurrence of 5 families in Ntakata Forest alone indicates that this place is relatively rich in butterfly diversity. Our results show that the Ntakata Forest provided habitat for butterfly abundance and included Metisella trisignatus trisignatus, Charaxes chepalungu, $C$. xiphares kiellandi and C. chunguensis (Nymphalidae), which are endemic to Tanzania [29]. The Study by Sinclair et al. [33] also reported a record of $C$. chunguensis in the Serengeti ecosystem in northern Tanzania. Our survey has also revealed the existence of the known as migrants. When applied to butterflies, the term 'migrant' generally means species that occasionally erupt and then irrupt; both Bicyclus safitza safitza, Pentila pauli clarensis and Bicyclus buea were recorded in the Ntakata Forest and were the most commonly found species (Appendix 1). Although most Ntakata butterfly species are residents, we recorded 14 migrants species (Appendix 1). Although most of these have a wide distribution, global or across Africa [29], they are either abundant or common in the study area.

Our study highlights basic patterns at species richness, generic and family levels across five habitat types after standardizing researcher efforts echoing Fitzherbert et al. [1]. First, we found significant low species richness and abundance in grassland, possibly because grassland plain contains fewer trees, shrubs and herbs that provide food for butterflies. Second, in cultivated areas adjacent to the Katavi National Park, Fitzherbert et al. [1] found a similar pattern. Third, they argued that habitats highly altered by humans contain fewer forest-dependent species, which would reduce the total number of species found in this habitat type.

However, species in Nymphalidae are the grassland specialists, but not species from Pieridae, unlike the report by Fitzherbert et al. [1], who reported that most species in the Pieridae family are generally grassland specialists and accordingly are more abundant and diverse in grassland habitat in Katavi National Park. Both Katavi and Ntakata are in western Tanzania, and both are dominated by miombo woodlands, though the proportions of forest differ greatly. In our study area, Nymphalidae had higher abundance, species richness and diversity in grassland habitat than Pieridae. One reason could be the absence of particular species of Pieridae that prefer to forage in grassland habitat in the Ntakata Forest or simply that we could not capture Pieridae in our study site. But we think that fewer catches of Pieridae in Ntakata Forest suggest the effects of elevation: Ntakata is on higher elevation compared to Katavi National Park. Future studies need to focus on these differences by collecting butterflies in both seasons, focusing on grassland to investigate this dichotomy.

Second, Forest habitat type was highly diverse taxonomically compared to other habitat types, followed by open woodland, closed woodland, and least grassland. Our findings echo the report in Katavi National Park [1] that riverine forest was the most diverse habitat types. The explanation for higher species diversity in the forest may include; available forest cover, water and the significant number of flowering tree species, microclimates, and many butterfly larval associated plant species [36] butterflies species diversity.

Third, while it is well established that there many butterfly species that occur in all habitat types (generalists) that mainly happen in the Mbuga habitat [1]. In our study, we found species composition similarities among different habitat types (Appendix 1). For example, open woodland versus forest had $40 \%$ in typical, open woodland versus closed woodland were $32 \%$ common, while closed woodland versus forest was $30 \%$ common. These results suggest that butterflies are habitat specialists, in line with Musarandega [36]. Forest and woodlands have plant cover, diverse food abundance and flowering tree plant species diverse from the lower habitat layer to the top canopies influencing butterflies diversity [36]. The presence of many flowering plants in these habitats and plant species association among butterfly species may be the reasons for such patterns [36], besides plant cover. Musarandega [36] found that the highest butterfly abundance and species diversity in the woodland was the best conditions for butterflies' survival, such as structural elements for sun-basking, mating, feeding, and even suitable microclimates in the habitat structure. Similarly, Didham \& Springate [37] and Barua [14] observed that tropical butterfly species attain maximum adult abundance in the forest with suitable microclimates. In addition, the study noted that the availability of adequate larval and adult feed sources influence the abundances of the adult population. These findings suggest that the pattern observed in our study forest, open woodland and closed woodland are ideal habitats for butterflies' survival, thus higher abundance and diversity. 
Overall, vegetation heterogeneity significantly influenced butterfly abundance and diversity in Ntakata Forest. The findings align with other previous works [11,38,39], who reported the same conclusions in other countries. More recently, Fitzherbert et al. [1] in Katavi National Park of western Tanzania. It is worth noting that the data we analyzed were from a short-term wet season survey, which would influence the results we have presented. We think wet and dry season survey data could give more realistic results for a much better understanding of the environmental health of the Ntakata Forest to suggest better management decisions on its conservation of biodiversity therein.

\section{Conclusion and Recommendations}

This study shows that Ntakata Forest is relatively rich, diverse, and has a higher butterfly abundance. Such butterfly distribution and composition could be caused by vegetation heterogeneity that existed in Ntakata Forest. Butterflies had strong species composition similarities between different habitat types. However, ongoing human activities will ruin and affect Lepidoptera species richness, abundance and diversity. Therefore, such human encroachment requires an immediate intervention to protect biodiversity loss in Ntakata Forest. We also suggest that the adjacent human communities be involved in conserving biodiversity in the Ntakata Forest.

\section{Acknowledgement}

The authors would like to thank Issa Hamis, Kobra Rashid, Joseph Nkuki and Ally Mtunda to collect butterflies. In addition, we thank the Ntakata Village Game Scouts (VGSs) Ayoub Awadhi, Bugalu Hamis, Mswago Rehani, Hamis Madaha, Seif Mohamed, Mkiwa Msafiri and all Ntakata Forest leaders for their guidance during data collection. Furthermore, we recognize the materials and technical support offered by Tanzania Wildlife Research Institute (TAWIRI).

\section{Funding}

This study was carried out with financial support from Dr. Ally K. Nkwabi and Dr. Sood A. Ndimuligo.

\section{Research involving wildlife:}

All research work followed rules and guidelines for conducting wildlife research in Tanzania set by Tanzania Wildlife Research Institute (TAWIRI), which works very close with Tanzania Commission for Science and Technology (COSTECH).

Appendix 1: Butterfly species identified based on Kielland [28] and Larsen $[29,30]$ and the number of individuals of each species trapped in the Ntakata Forest, western Tanzania.

\begin{tabular}{|c|c|c|c|c|c|c|c|}
\hline \multirow[b]{2}{*}{ Family and Scientific Name } & \multirow[b]{2}{*}{ Distribution } & \multicolumn{4}{|c|}{ Habitat Type } & \multirow[b]{2}{*}{ Total Individuals } & \multirow[b]{2}{*}{$\%$ Capture } \\
\hline & & $\begin{array}{l}\text { Closed Wood- } \\
\text { land }\end{array}$ & Forest & Grassland & $\begin{array}{c}\text { Open } \\
\text { Woodland }\end{array}$ & & \\
\hline Hesperiidae & & 5 & 16 & 3 & 14 & 38 & 8.37 \\
\hline Borbo fatuellus fatuellus & Global & 1 & 2 & & 1 & 4 & 0.88 \\
\hline Chondrolepis telisignata & Local & & 3 & & 1 & 4 & 0.88 \\
\hline Coeliades forestan forestan & Regional & & & 1 & & 1 & 0.22 \\
\hline Coeliades libeon & Global & 1 & 1 & & & 2 & 0.44 \\
\hline Hypoleucis tripunctata draga & Local & & 2 & & & 2 & 0.44 \\
\hline Metisella midas midas & Regional & & & & 3 & 3 & 0.66 \\
\hline Metisella trisignatus trisignatus & Endemic & 2 & 1 & 2 & & 5 & 1.1 \\
\hline Monza alberti & Local & & 1 & & 1 & 2 & 0.44 \\
\hline Pardaleodes sator pusiella & Regional & & 1 & & & 1 & 0.22 \\
\hline Prosopalpus styla & Regional & 1 & & & & 1 & 0.22 \\
\hline Sarangesa maculata & Regional & & & & 2 & 2 & 0.44 \\
\hline Spialia dromus & Regional & & 1 & & 1 & 2 & 0.44 \\
\hline Spialia spio & Regional & & 1 & & 2 & 3 & 0.66 \\
\hline Tagiades flesus & Regional & & & & 2 & 2 & 0.44 \\
\hline Teniorhinus herilus & Local & & 1 & & & 1 & 0.22 \\
\hline Zenonia zeno & Regional & & 2 & & 1 & 3 & 0.66 \\
\hline Lycaenidae & & 18 & 16 & 1 & 52 & 87 & 19.16 \\
\hline Anthene butleri stempfferi & Regional & & 2 & & & 2 & 0.44 \\
\hline Azanus natalensis & Local & 2 & & & & 2 & 0.44 \\
\hline Epitola viridana viridana & Local & & 5 & & & 5 & 1.1 \\
\hline
\end{tabular}


International Journal of Environmental Sciences \& Natural Resources

\begin{tabular}{|c|c|c|c|c|c|c|c|}
\hline Euchrysops osiris & Global & 1 & & & & 1 & 0.22 \\
\hline Euchrysops subpallida & Local & & 1 & & 2 & 3 & 0.66 \\
\hline Leptotes pirithous & Global & & & 1 & 5 & 6 & 1.32 \\
\hline Lipaphnaeus loxura & Local & & 1 & & & 1 & 0.22 \\
\hline Ornipholidotos overlaeti & Local & 2 & & & & 2 & 0.44 \\
\hline Pentila pauli clarensis & Local & 11 & 3 & & 25 & 39 & 8.59 \\
\hline $\begin{array}{c}\text { Tuxentius margaritaceus mar- } \\
\text { garitaceus }\end{array}$ & Local & 2 & 2 & & 17 & 21 & 4.63 \\
\hline Uranothauma cordatus & Local & & 2 & & 3 & 5 & 1.1 \\
\hline Nymphalidae & & 93 & 69 & 11 & 82 & 255 & 56.17 \\
\hline Acraea acrita & Regional & & & 4 & & 4 & 0.88 \\
\hline Acraea bonasia & Regional & 1 & & & & 1 & 0.22 \\
\hline Acraea encedana & Local & 1 & 2 & & & 3 & 0.66 \\
\hline Acraea peneleos pelasgius & Regional & & 1 & & & 1 & 0.22 \\
\hline Acraea pharsalus pharsalus & Regional & & & 1 & & 1 & 0.22 \\
\hline Acraea viviana & Regional & & 1 & & & 1 & 0.22 \\
\hline Amauris niavius niavius & Regional & & 1 & & 2 & 3 & 0.66 \\
\hline Amauris tartarea & Regional & & 1 & & & 1 & 0.22 \\
\hline Aterica galene galene & Regional & 2 & & & 1 & 3 & 0.66 \\
\hline Bebearia chriemhilda & Local & 1 & & & & 1 & 0.22 \\
\hline Bicyclus buea & Local & 24 & 6 & 2 & 1 & 33 & 7.27 \\
\hline Bicyclus campus & Local & 2 & & & & 2 & 0.44 \\
\hline Bicyclus golo & Local & & 1 & & & 1 & 0.22 \\
\hline Bicyclus mollitia & Local & 1 & & & & 1 & 0.22 \\
\hline Bicyclus safitza safitza & Local & 18 & 7 & & 15 & 40 & 8.81 \\
\hline Bicyclus smithi smithi & Local & 1 & 3 & & 1 & 5 & 1.1 \\
\hline Catuna crithea conjuncta & Local & & 1 & 1 & 1 & 3 & 0.66 \\
\hline Charaxes acuminatus & Regional & & & & 1 & 1 & 0.22 \\
\hline Charaxes brutus & Regional & 2 & & & 2 & 4 & 0.88 \\
\hline Charaxes chepalungu & Endemic & & & 1 & & 1 & 0.22 \\
\hline Charaxes chunguensis & Endemic & & & & 1 & 1 & 0.22 \\
\hline Charaxes etesipe etesipe & Regional & & & & 1 & 1 & 0.22 \\
\hline Charaxes tiridates & Regional & & & & 2 & 2 & 0.44 \\
\hline Charaxes violetta maritimus & Local & & 1 & & 1 & 2 & 0.44 \\
\hline Charaxes xiphares kiellandi & Endemic & & 2 & & & 2 & 0.44 \\
\hline Cymothoe coranus & Regional & & & & 1 & 1 & 0.22 \\
\hline Euphaedra hollandi & Local & & & 1 & & 1 & 0.22 \\
\hline Gnophodes betsimena diversa & Regional & 13 & 5 & & 9 & 27 & 5.95 \\
\hline Hamanumida daedalus & Global & 1 & & & 2 & 3 & 0.66 \\
\hline Harma theobene blassi & Local & 2 & & & & 2 & 0.44 \\
\hline Junonia chorimene & Global & 2 & 2 & & 2 & 6 & 1.32 \\
\hline Junonia stygia gregorii & Regional & 1 & 8 & & 5 & 14 & 3.08 \\
\hline Junonia terea & Local & 1 & 1 & & 5 & 7 & 1.54 \\
\hline Kallimoides rumia rattrayi & Local & 2 & 2 & & 2 & 6 & 1.32 \\
\hline
\end{tabular}


International Journal of Environmental Sciences \& Natural Resources

\begin{tabular}{|c|c|c|c|c|c|c|c|}
\hline Melanitis libya & Regional & 10 & 4 & & 7 & 21 & 4.63 \\
\hline Neptidopsis ophione velleda & Regional & & 1 & & & 1 & 0.22 \\
\hline Neptis penningtoni & Local & 1 & 2 & & 2 & 5 & 1.1 \\
\hline Phalanta eurytis eurytis & Regional & & 1 & & 1 & 2 & 0.44 \\
\hline Phalanta phalantha & Global & & & & 5 & 5 & 1.1 \\
\hline Precis archesia & Local & 1 & 2 & & 1 & 4 & 0.88 \\
\hline Precis octavia sesamus & Regional & & & 1 & & 1 & 0.22 \\
\hline Precis tugela & Regional & & 1 & & & 1 & 0.22 \\
\hline Protogoniomorpha parhassus & Regional & & & & 2 & 2 & 0.44 \\
\hline $\begin{array}{l}\text { Pseudacraea deludens echeri- } \\
\text { oides }\end{array}$ & Local & 1 & 1 & & & 2 & 0.44 \\
\hline Pseudacraea lucretia protracta & Regional & & 1 & & & 1 & 0.22 \\
\hline Pseudargynnis hegemone & Regional & 1 & 8 & & 2 & 11 & 2.42 \\
\hline Vanessula milca latifasciata & Regional & 1 & 3 & & 1 & 5 & 1.1 \\
\hline Ypthimomorpha itonia & Regional & 3 & & & 6 & 9 & 1.98 \\
\hline Papilionidae & & 2 & 9 & & 16 & 27 & 5.95 \\
\hline Graphium leonidas leonidas & Global & & 1 & & 1 & 2 & 0.44 \\
\hline Graphium policenes & Regional & & 1 & & 1 & 2 & 0.44 \\
\hline Papilio chrapkowskoides & Regional & & 1 & & 3 & 4 & 0.88 \\
\hline Papilio dardanus & Regional & & 2 & & 1 & 3 & 0.66 \\
\hline Papilio echerioides joiceyi & Local & & & & 2 & 2 & 0.44 \\
\hline Papilio hesperus & Regional & & & & 1 & 1 & 0.22 \\
\hline Papilio nireus lyaeus & Global & & 2 & & 1 & 3 & 0.66 \\
\hline $\begin{array}{l}\text { Papilio ophidicephalus ophid- } \\
\text { icephalus }\end{array}$ & Global & 1 & & & & 1 & 0.22 \\
\hline Papilio phorcas & Global & 1 & 2 & & 6 & 9 & 1.98 \\
\hline Pieridae & & 5 & 15 & 1 & 26 & 47 & 10.35 \\
\hline Belenois solilucis & Local & 2 & 1 & & & 3 & 0.66 \\
\hline Catopsilia florella & Global & & 1 & & & 1 & 0.22 \\
\hline Eurema desjardinsii marshalli & Regional & & 1 & & 2 & 3 & 0.66 \\
\hline Eurema hapale & Local & 1 & 3 & & 3 & 7 & 1.54 \\
\hline Eurema hecabe solifera & Global & & & & 1 & 1 & 0.22 \\
\hline Eurema regularis regularis & Local & 2 & 3 & 1 & 11 & 17 & 3.74 \\
\hline Eurema senegalensis & Regional & & 1 & & 8 & 9 & 1.98 \\
\hline Eurema upembana & Local & & 1 & & 1 & 2 & 0.44 \\
\hline Mylothris agathina & Global & & 1 & & & 1 & 0.22 \\
\hline Mylothris similis similis & Local & & 1 & & & 1 & 0.22 \\
\hline Nepheronia argia argia & Regional & & 1 & & & 1 & 0.22 \\
\hline Nepheronia argia argolisia & Regional & & 1 & & & 1 & 0.22 \\
\hline
\end{tabular}

Source: General distribution notes from Larsen [29].

\section{References}

1. Fitzherbert E, Gardner T, Davenport TR, Caro T (2006) Butterfly species richness and abundance in the Katavi ecosystem of western Tanzania. African Journal of Ecology 44(3): 353-362.

2. Caro TM, Pelkey N, Borner M, Campbell KI, Woodworth B, et al. (1998)
Consequences of different forms of conservation for large mammals in Tanzania: preliminary analyses. African Journal of Ecology 36(4): 303-320.

3. Kano T (1971) Distribution of the primates on the eastern shore of Lake Tanganyika. Primates 12(3-4): 281-304. 
4. Kano T (1972) Distribution and adaptation of the chimpanzee in the open country on the eastern shore of Lake Tanganyika. Kyoto University of African Studies 7: 37-129.

5. Moyer D, Plumptre A, Pintea L, Aguilar AH, Moore J, et al. (2006) Surveys of chimpanzees and other biodiversity in Western Tanzania. Unpublished report. Arlington, VA: United States Fish and Wildlife Service (USFWS).

6. Piel AK, Cohen N, Kamenya S, Ndimuligo SA, Pintea L, et al. (2015) Population status of chimpanzees in the Masito-Ugalla Ecosystem, Tanzania. American Journal of Primatology 77(10): 1027-1035.

7. Houlahan JE, Findlay CS, Schmidt BR, Meyer AH, Kuzmin SL (2000) Quantitative evidence for global amphibian population declines. Nature 404(6779): 752-755.

8. Mac Nally R, Fleishman E, Bulluck LP, Betrus CJ (2004) Comparative influence of spatial scale on beta diversity within regional assemblages of birds and butterflies. Journal of Biogeography 31(6): 917-929.

9. Stuart SN, Chanson JS, Cox NA, Young BE, Rodrigues AS, et al. (2004) Status and trends of amphibian declines and extinctions worldwide. Science 306(5702): 1783-1786.

10. Daily GC, Ehrlich PR (1995) Preservation of biodiversity in small rainforest patches: rapid evaluations using butterfly trapping. Biodiversity and Conservation 4(1): 35-55.

11. Hamer K, Hill J, Benedick S, Mustaffa N, Sherratt T, et al. (2003). Ecology of butterflies in natural and selectively logged forests of northern Borneo: the importance of habitat heterogeneity. Journal of Applied Ecology 40(1): 150-162.

12. Koh LP, Sodhi NS, Brook BW (2004) Co-extinctions of tropical butterflies and their hostplants. Biotropica 36(2): 272-274.

13. Molleman F, Kop A, Brakefield PM, Zwaan BJ (2006) Vertical and temporal patterns of biodiversity of fruit-feeding butterflies in a tropical forest in Uganda. Biodiversity and Conservation 15(1): 107121

14. Barua KK (2008) Diversity and habitat selection of Papilionidae in a protected forest reserve in Assam. Gottingen University, Northeast India.

15. Mligo C, Lyaruu H, Ndangalasi HJ (2011) The effect of anthropogenic disturbances on population structure and regeneration of Scorodophloeus fischeri and Manilkara sulcata in coastal forests of Tanzania. Journal of Forest Science 73(1): 33-40.

16. Katircioglu ST (2014) International tourism, energy consumption, and environmental pollution: The case of Turkey. Renewable and Sustainable Energy Reviews 36: 180-187.

17. Sawchik J, Dufrêne M, Lebrun P (2005) Distribution patterns and indicator species of butterfly assemblages of wet meadows in southern Belgium. Belgian Journal of Zoology 135(1): 43-52.

18. Plumptre AJ, Davenport TR, Behangana M, Kityo R, Eilu G, et al. (2007) The biodiversity of the Albertine Rift. Biological Conservation 134(2): 178-194.

19. John J, Kohi E, Park JY, Nkwabi A, Choi CY, et al. (2019) Birds of Western Tanzania (Gombe, Mahale, Rubondo, Saanane, Malagarasi, Ntakata, Minziro). Doohyun Publishing Co, National Institute of Biological Resources (NIBR), Korea.

20. Katensi S (2015) Ntakata Forest monitoring report for a period of october 2013-march 2015.
21. Ubc (2013) (United Bank of Carbon) - in association with the Tongwe Trust and Fauna and Flora International.

22. Osei BA (2012) Effects of Human Disturbance on Butterfly Diversity and Abundance in Atewa Range Forest Reserve, Ghana. (MSc Thesis) Kwame Nkrumah University of Science and Technology, Kumasi, Ghana.

23. Hoyle M, James M (2005) Global warming, human population pressure, and viability of the World's smallest butterfly. Conservation Biology 19(4): 1113-1124.

24. James M, Gilbert F, Zalat S (2003) Thyme and isolation for the Sinai baton blue butterfly (Pseudophilotes sinaicus). Oecologia 134(3): 445453.

25. Ogawa H, Moore J, Kamenya S (2006) Chimpanzees in the Ntakata and Kakungu areas, Tanzania. Primate Conservation, pp. 97-101.

26. Kibaja M (2014) Diet of the ashy red colobus (Piliocolobus tephrosceles) and crop-raiding in a forest-farm mosaic, Mbuzi, Rukwa Region, Tanzania. Primate Conservation 28: 109-116.

27. Nkwabi AK, Liseki H, Bukombe JK, Kija H, Mmassy E, et al. (2017) Species richness and composition of butterfly with reference to anthropogenic activities in the wildlife management areas, Southern Tanzania. International Journal of Fauna and Biological Studies 4(1): 34-40.

28. Kielland J (1990) Butterflies of Tanzania. Hill House, Melbourne/ London.

29. Larsen TB (1996) The butterflies of Kenya and their Natural history. Oxford University Press, Oxford.

30. Larsen TB (2005) Butterflies of West Africa. Apollo Books, Stenstrup, Denmark

31. Thomas JA (1983) A quick method for estimating butterfly numbers during surveys. Biological Conservation 27(3): 195-211.

32. Munyuli MB (2012) Butterfly diversity from farmlands of central Uganda. Journal of Entomology 2012: 1-23.

33. Sinclair ARE, Nkwabi A, Metzger KL (2015) The butterflies of Serengeti: Impact of environmental disturbance on biodiversity. In: Sinclair ARE, Metzger K, Mduma SAR, Fryxell J (Eds.), Serengeti IV: Sustaining Biodiversity in a Coupled Human-Natural System, University of Chicago Press, Chicago, pp. 301-321.

34. Seaby RMH, Henderson PA (2007) Species Diversity and Richness version 4.1.2. Pisces Conservation Ltd, Lymington.

35. Magurran AE (2004) Measuring Biological Diversity. Blackwell, Oxford.

36. Musarandega L (2015) Butterfly species diversity and abundance at the Khami World Heritage Site. (MSc Thesis), Bindura University of Science Education (BUSE), Zimbabwe.

37. Didham RK, Springate ND (2003) Determinants of temporal variation in community structure. In: Basset Y, Novotny V, Miller SE, Kitching RL (Eds.), Arthropods of tropical forests: Spatio-temporal dynamics and resource use in the canopy, Cambridge University Press, Cambridge, pp. 28-39.

38. Tiple AD, Khurad AM (2009) Butterfly species diversity, habitats and seasonal distribution in and around Nagpur City, central India. World Journal of Zoology 4(3): 153-162.

39. Bonebrake TC, Ponisio LC, Boggs CL, Ehrlich PR (2010) More than just indicators: a review of tropical butterfly ecology and conservation. Biological Conservation 143(8): 1831-1841. 
(CC) This work is licensed under Creative

(C) DOI:10.19080/IJESNR.2021.28.556235
Your next submission with Juniper Publishers will reach you the below assets

- Quality Editorial service

- Swift Peer Review

- Reprints availability

- E-prints Service

- Manuscript Podcast for convenient understanding

- Global attainment for your research

- Manuscript accessibility in different formats ( Pdf, E-pub, Full Text, Audio)

- Unceasing customer service

Track the below URL for one-step submission https://juniperpublishers.com/online-submission.php 